University of New Hampshire

University of New Hampshire Scholars' Repository

$2-2009$

\title{
Complex Personhood as the Context for Intimate Partner Victimization: One American Indian Woman's Story
}

Sharon B. Murphy

University of New Hampshire

Lynne Lemire

Mindi Wisman

Follow this and additional works at: https://scholars.unh.edu/pirc

Part of the Domestic and Intimate Partner Violence Commons

\section{Recommended Citation}

Murphy, S., Lemire, L., \& Wisman, W. (2009). Complex Personhood as the Context for Intimate Partner Victimization: One American Indian Woman's Story. American Indian and Alaska Native Mental Health Research: The Journal of the National Center, 16, 39-59.

This Article is brought to you for free and open access by the Prevention Innovations Research Center (PIRC) at University of New Hampshire Scholars' Repository. It has been accepted for inclusion in Peer-Reviewed and Other Publications by an authorized administrator of University of New Hampshire Scholars' Repository. For more information, please contact Scholarly.Communication@unh.edu. 


\title{
COMPLEX PERSONHOOD AS THE CONTEXT FOR INTIMATE PARTNER VICTIMIZATION: ONE AMERICAN INDIAN WOMAN'S STORY
}

\author{
Sharon Murphy, Ph.D., ACSW, Lynne Lemire, MSW, \\ and Mindi Wisman, MSW
}

\begin{abstract}
This qualitative case study explores one American Indian (Al) woman's experience of intimate partner violence and the subsequent murder of her abusive partner. The lens of complex personhood (Gordon, 1997) has been applied as a method for understanding "Annie's" multiple identities of Al woman, victim of intimate partner violence, mother, and convicted felon. The aim of the current case study was to uncover implicit and explicit meanings embedded in the experiences of moving from a victim of IPV to an offender by applying a framework of hermeneutic phenomenology as the methodology. Three relational themes emerged from the interview data: "Getting out of Hand," "They're in my Footstep all the Way Now," and "What's a Miranda Right"? Lastly, this article begins an exploration into the complex link between victimization and offending as it applies to one battered woman.
\end{abstract}

\section{Case Study}

Annie ${ }^{1}$ is an enrolled member of an American Indian (Al) nation in the Southwest. Her native language is her first language; English is her second language. She is approximately 50 years old and was educated in a boarding school, as were many Al people from her generation. Annie spent her youth on the reservation until she left for boarding school at age 14. Upon graduation from high school she returned to the 
reservation where she met a young man with whom she had her first child. That relationship was marked with violence, and Annie left the reservation with her son when he was about 1 year old. Like many other Al people, Annie chose to leave the reservation to look for employment and new opportunities for herself and her young son. Shortly after arriving in a metropolitan area she met John.* He was non-Native and, as Annie later discovered, had recently been released from prison for stabbing his pregnant former girlfriend. Annie and John quickly became involved with each other and soon began living together. John worked sporadically throughout the years and made it nearly impossible for Annie to maintain a job. When she did work, he would call her many times a day and show up unannounced, even though she would beg him not to get her in trouble with her employer. They had two children together in addition to Annie's son from her previous relationship. John's use of physical violence began almost immediately, including punches to the mouth knocking out Annie's teeth, blows to parts of her body covered by clothing, rape and sexual assault, and a never-ending barrage of verbal taunts. These acts continued throughout their 20-year relationship. Additionally, John was addicted to alcohol and drugs, predominantly inhalants.

One night when the two returned from a bar, the violence and abuse escalated. John's blows were harder. He threw her against the wall and pummeled her with his fists. His verbal tirade stung more sharply. Physically and emotionally crushed, Annie attempted to take her own life with a knife. John came toward her one last time, and she struck back with the knife she had been using on herself. John staggered away, bleeding profusely; he died within minutes.

Annie called 911 and told the dispatcher that John was bleeding heavily and not moving. She was arrested and charged with seconddegree murder. After approximately 1 week in county jail, Annie was released in her own recognizance. Her trial was held 4 years after John's death. At trial she was convicted of negligent homicide and served 3 years in a state prison (the crime was committed off of Indian land). When her public defender succeeded in obtaining a hearing before the Clemency Review Board, ${ }^{2}$ a split vote resulted in the completion of her prison sentence. Upon her release, Annie returned to the reservation where all of her children, now adults, also reside. Annie is now impoverished and struggling to make ends meet. 


\section{Introduction}

Although Annie's story may sound extreme, the severity and frequency of the violence she experienced at the hands of her longtime partner is, unfortunately, all too common in the U.S.. The National Violence Against Women Survey (Tjaden \& Thoennes, 1998), a nationally representative telephone survey of 8,000 women and 8,000 men about their experiences with rape, physical assault, and stalking, reports that 1.3 million women in the U.S. are victims of intimate partner violence (IPV) annually. Furthermore, $17.6 \%$ of surveyed women stated that they had been physically assaulted sometime during their lifetime. According to the Bureau of Justice Statistics (2006), the overall annual rate of nonfatal domestic violence from 1993 to 2004 was higher for females in all racial groups than for their male counterparts. Although 30 years of research have provided activists, researchers, and practitioners with important information about IPV, gaps still plague our understanding of the full scope of the problem and all of its tendrils.

One area that has not received much attention is the experience of American Indian and Alaska Native (AI/AN) women victims of IPV (Bohn, 2003; Bubar \& Thurman, 2004; Deer, Clairmont, Martell \& White Eagle, 2008; Hamby, 2000; Harwell, Moore, \& Spence, 2003; Murray, 1998; Murphy, Gerdes, Risley-Curtiss, 2004; Saylors \& Daliparthy, 2006; Wahab and Olson, 2004; Waller, Risley-Curtiss, Murphy, Medill, \& Moore, 1998). Oetzel and Duran (2004) note that although this area of research continues to be limited, studies do support the fact that IPV is more prevalent among Al/ANs than other groups. They review 4 studies of $\mathrm{Al} / \mathrm{AN}$ women's victimization and conclude that Al/AN women are more likely to be killed by an intimate partner and are at greater risk for lifetime prevalence of IPV.

Al/ANs comprise approximately $1.5 \%$ of the U.S. population (U.S. Census Bureau, 2000) and speak approximately 200 different languages (Hamby, 2000). Al/ANs are a diverse group of independent sovereign nations. Some non-Natives tend to group all Al/ANs into one homogenous group, blurring the boundaries between and among them and denying the unique cultures, traits, traditions, and characteristics of the over $560 \mathrm{Al} / \mathrm{AN}$ nations (Bureau of Indian Affairs, 2008). Grouping all $\mathrm{Al} / \mathrm{ANs}$ ignores the possibility of culturally specific remedies and can lead to the adoption of one-size-fits-all intervention and treatment models fashioned after the dominant culture. It also fails to acknowledge individual $\mathrm{Al} / \mathrm{AN}$ nations, their identities, sovereignty, and distinct cultures. 


\section{IPV in an Historical Context}

Although current rates of IPV and sexual assault are high in Indian Country, traditionally, domestic violence was not accepted as a normative way of life by Al communities (Rivers, 2005). Murray (1998) notes that domestic violence was discouraged through practices such as long courtships, fear of retribution by the woman's family members, extended-family meetings, marriage laws which reflected the importance and protection of women, and matrilocal residence, to name a few. When domestic violence did occur, individual communities dealt with it in a community-appropriate way, by banishment, divorce, or other methods (Agtuca, 2008; Murray; Zion \& Zion, 1993).

Agtuca (2008) notes that historical documentation from the 1700 s describes Iroquois women as leaders within their communities. She further states that oral teachings handed down by individual tribes through the generations have formed what today is known as common law and defines respect and safety for Native women prior to European contact. Agtuca states that violence against Native women in precolonial times was addressed within the worldview and spiritual beliefs of individual tribes, was dealt with harshly, and was not sanctioned by law (as it was in British common law). Bubar and Thurman (2004) note that the place of women within tribal communities has been altered through the destruction of traditional support systems for women as well as through the view of women from the dominant culture's perspective, while Agtuca states that Al women's roles and status have been eroded with the removal of the authority of Al nations to protect women in their communities. Numerous authors state that IPV must be understood from an historical perspective and that many of today's social problems within Al communities can be traced to the erosion (caused by the laws and practices of the U.S. federal government) of traditions, cultures, gender roles, and, most notably, the legal authority of tribal governments to protect their women citizens (Agtuca; Allen, 1992; Bubar \& Thurman; Chester, Robin, Koss, Lopez, \& Goldman, 1994; Deer et al., 2008; Deloria \& Lytle, 1983; Duran \& Duran, 1995; Jaimes, 1992; Lujan, 1995; Rivers, 2005).

The Bureau of Justice (2004) notes that, when compared to the non-AI female population in the U.S., AI women are a small group, yet they experience violent victimization (domestic violence, sexual assault, and rape) at a rate $2 \frac{1}{2}$ times greater than that of all other U.S. females. Likewise, Al women are at least twice as likely to be sexually assaulted in their lifetime, as compared to all races (Bureau of Justice Statistics, 
2004). Additionally, this report states that impoverished urban Al women in interracial marriages or relationships are among those at the highest risk of violent victimization. According to Lobe (2007), at least 1 in 3 $\mathrm{Al} / \mathrm{AN}$ women will be raped or sexually assaulted in her lifetime, versus fewer than 1 in 5 non-Al women nationwide. Equally noteworthy is the ethnicity of the abuser in those cases. At least $86 \%$ of sexual assaults of $\mathrm{Al} / \mathrm{AN}$ women on tribal lands are by non-Al/AN men who are rarely punished or prosecuted for their actions (Lobe). Most reports on AI/AN violence and victimization are not tribally specific, leading to general data on violence and victimization in Indian Country.

\section{Battered Women and the Criminal Justice System}

There are distinct differences in the context and quality of violence used by women and men. Women are found to use violence as a means of self-defense, retaliation for prior physical violence and psychological battering, or to escape violence, while men use it as a means of control and domination over their female partners (Miller, 2001; Owen, 2001). Straus' 1993 study reports the differences in the use of violence and shows that women use violence (e.g., beating on their partner's chest, slapping) out of anger or frustration or because of a lack of communication in the relationship, whereas men use violence (e.g. hitting or threatening to hit) to force a specific behavior from their partner. Likewise, Steffensmeier \& Allan (1996) write that women are more likely to kill after a prolonged period of abuse, when they fear for their own safety or that of their children, or after they have exhausted other possibilities. Miller (2001) argues for a contextual understanding of battered women's use of violence against an intimate partner.

Unfortunately, there are no national studies that report the number of women victims of IPV who are incarcerated for killing their batterer. Chesney-Lind and Pasko's review (2004) of the literature on the link between women's prior victimization and criminal offending reports that half of all incarcerated women have experienced IPV by a spouse or ex-spouse. There are also some studies pertaining to specific correctional facilities that report a linkage between IPV and incarceration for a criminal offense. For example, Bradley and Davino (2002) report that in a sample of 65 incarcerated women, $84.6 \%$ reported a history of physical violence in an adult relationship. Additionally, Browne, Miller, and Maguin (1999) found $75 \%$ of the incarcerated women in a New York state prison had experienced severe physical violence by an 
intimate partner. Chesney-Lind and Pasko (2004) report 98\% of women convicted of homicide have killed an intimate partner, family member, or acquaintance, whereas among men convicted of homicide, only $76 \%$ have killed someone they knew.

Ferraro (2006) eloquently describes the inherent difficulties in conceptualizing and responding to women who, following years of violence and abuse, react with violence against their perpetrators. Our understanding of this dynamic is complicated by language; consequently, words such as "victim" and "offender" become inadequate to explain the phenomenon in which a battered woman takes the life of her abusive partner. The boundary between victim and offender becomes blurred as we struggle to understand culpability and justice, guilt and innocence. Is it possible that Annie is neither an "angel nor a demon"? Do we need a new term for the experiences of battered women who take the life of their perpetrator? Annie's multiple identities of AI woman, victim of IPV, mother, and felon combine in such a way that we can visualize Hill Collins' "intersecting oppressions" (2000, p. 25) in Annie's personhood.

The aim of the current study was to uncover implicit and explicit meanings embedded in the experiences of moving from a victim of IPV to an offender. The lens of "complex personhood" (Gordon, 1997, p.4) is applied to the case study of Annie in an effort to explore the extraordinary complexity of her life. According to Gordon:

complex personhood means that all people (albeit in specific forms whose specificity is sometimes everything) remember and forget, are beset by contradiction, and recognize and misrecognize themselves and others. Complex personhood means that people suffer graciously and selfishly too, and get stuck in the symptoms of their troubles, and also transform themselves. Complex personhood means even those called 'Other' are never never that. Complex personhood means that the stories people tell about themselves, about their troubles, about their social worlds, and about their society's problems are entangled and weave between what is immediately available as a story and what their imaginations are reaching toward.

Added to the complexity that describes Annie's life is language. Annie's first language is her native language, and although she speaks English, it is clear that there are many times when meanings are different than 
what she intends or when she does not fully understand the meaning of the English-language speaker. For Annie, the complexity of language became a context for what had already transpired and what would lie ahead.

\section{Role of Domestic Violence Expert}

As noted in the Case Study, Annie was charged with seconddegree murder and was ultimately convicted of negligent homicide and served 3 years in a state penitentiary. I (the first author) was hired by the public defender to provide expert testimony on domestic violence at Annie's trial and, in that capacity, was given copies of all of the pertinent court records, as well as the photographs taken of Annie's self-inflicted stab wounds, her old scars and bruises, and pictures of holes in the wall and broken furniture in the apartment. I interviewed Annie approximately two years prior to her trial for 20 hours. My job involved amassing information about her life, including her 20 years as John's intimate partner. My role was to assess and determine whether she was a victim of John's violence, and, if so, to assess the level of severity of the abuse/violence. Lastly, I was required to provide a written report of my findings to the court and to testify at her murder trial and, later, at a hearing before the Clemency Review Board, and the Governor of the State. Her request for clemency was denied and her conviction of negligent homicide remained. Annie completed her sentence in the state prison complex. Approximately 10 years after interviewing Annie pre-trial, I interviewed her again, now in the role of researcher from an academic institution. I wanted to understand Annie's dual experiences of victim and offender. In response to my questions, Annie talked about the violence she experienced at John's hands, as well as her fears and concerns about the impact of John's abuse and violence on their children. Annie was unable to answer my questions "What happened that caused you to feel like you had to defend your life that night? How did you get from victim to offender?" She simply said: "I don't know how to answer that."

Was my question about her actions and the motive behind them so poorly worded that Annie didn't understand my meaning? Had she not attempted to explain to herself what made her finally cross the line? Were there multiple reasons, or were her reasons so emotionally complex that they defied her vocabulary? Annie's response to the questions 
was clear; she maintained that she was simply trying to stop John from attacking her again when she took the knife out of her chest and put it into his-nothing more than an act of self-preservation.

At first I thought that she was evading my question, so I repeated it several times during the interview, always with the same result. Weeks later, as I re-read the transcript again, I realized that she had answered me. Once again, Annie talked about feeling trapped, that there was nowhere to run and that wherever she went he would find her. This was her answer; she answered with what was on her mind--the abuse and violence would always be with her, it would always be a part of her life. Today the abuse and violence are still present-in her memories of John and enacted in the lives of her children.

\section{Method}

In this study, Heideggerian hermeneutic phenomenology (Diekelmann \& Allen, 1989) was used to bring to light Annie's lived experience of victimization and her new role of offender. According to German philosopher Martin Heidegger, phenomenology should make manifest what is hidden in ordinary everyday experience, making it particularly appropriate as an application to this project (Heidegger, 1953/1996). It is ultimately concerned with the meanings that individuals make of their experiences, always acknowledging that meanings are embedded within a particular historical and cultural context and against the backdrop of the subject's personal background. Rather than enter into a study with a theoretical framework by which the researcher attempts to interpret others' words, this philosophy and methodology asks that we leave ourselves open to many different interpretations.

This methodology was used as a framework for reflecting, interpreting, and gaining insight into the meaning Annie attributed to her experience with domestic violence at the hands of John, as well as the ways in which she made sense out of moving from victim to offender. Following the interpretivist paradigm, this philosophy of science and methodology enjoins the participant and researcher into a process of co-constructing the phenomenon under study; hence the usefulness of gathering from Annie her understanding, or meaning-making, of victimization and offending. Annie's telling of her story was audio-taped, and her words became the texts for analysis.

I received approval from the university's Institutional Review Board for the Protection of Human Subjects to conduct face-to-face interviews with Annie at a site near her reservation. ${ }^{3}$ Prior to audio- 
taping Annie's story, I reviewed with her the purpose of the study, informed consent, a confidentiality statement, and the risks and benefits of participating in the research. Additionally, I gave her a list of area resources that would be available if she chose to seek assistance following the interviews. Interviews took place over the course of approximately 10 hours. The audiotapes were kept in a locked file cabinet in my office and were destroyed upon completion of the project. I formed a research team with my research assistant and a graduate student (co-authors on this project). The data for this study included 40 transcribed pages. Transcription was provided by a member of the research team.

Throughout the process of gathering emerging themes from the transcripts, the team chose not to change Annie's words in order to fit a common dialect. Rather, we chose to follow DeVault's rationale regarding the use of a woman's own words in order to "recover and examine unnoticed experience" (1990, p. 107). DeVault argues that by altering a woman's words, we discount her language and experience. As such, Annie's words are reproduced as they were spoken. If we had altered her words to fit our interpretation, we would have engaged in a process of sterilization, distortion, and extinction of Annie's identity.

\section{Stages of Analysis}

Diekelmann and Allen's (1989) stages of analysis were used to carry out the methodology. As a component of this analytic format, the research team met over the course of 3 months to read the text and to extract emerging themes from the interview data. During this process, the team continually returned to the text for clarification of interpretation. Notes from each team meeting were recorded, transcribed, and disseminated to the team members. Team members met to draw out emerging themes from the text, to engage in warranting the data, and finally to extract relational themes (themes that cut across texts).

\section{Findings}

Three relational themes emerged from the data. The themes "Getting out of hand," "They're in my footstep all the way now," and "What's a Miranda right?" were taken from phrases spoken by Annie as her story unfolded. I use them here as labels to describe Annie's experience. 


\section{Getting out of hand}

The first theme reflects the complexity of Annie's experience. It is clear that things got "out of hand" when Annie attempted to take her own life and then struck back at John in an attempt to stop him from coming toward her in what she describes as self-defense.

I had a problem with him, he was always jealousy and everything but I managed to be with him all those days, all the years, until he got to the point when he was getting out of hand...

Annie is not only a victim of John's violence but she is also a victim of her circumstances. Impoverished with three children and no vehicle for transportation, her choices were limited. The biggest limitation, however, was not a lack of transportation; it was instead, her inability to escape.

I wish that time I would've walked out, would've walked out with my kids. But I can't get too far because he know[s] where I live at. He will always follow me wherever I went, my kids, he would always find out where I'm at... he knows where I live...I wanted to get away from him but there was no way to run. I was trapped; wherever I go he was always gonna find me.

Fear seems to be another component of this theme; Annie states that she was always afraid of John. She describes fear in the following way: "What was gonna happen? What was he gonna do? How was it gonna be when he comes home?"

Juxtaposed with feelings of entrapment and fear is Annie's belief that she needed to be able to withstand his abuse and remain in the relationship. Isolated from family and friends, living in a large urban center, and surrounded only by John's family, Annie did not see many choices. She states that she never thought she would leave him, and that remaining with him took strength, resolve, and courage. There seems to be a mix of determination to withstand his abuse, a belief that her place was with him, and the knowledge that she would never be able to escape. This belief was, at least in part, based on two experiences in which she had attempted to leave him, only to be tracked down and brought back home: 
... I managed to get away with my family, got away from him, traveled back home, came back home but later on he followed me. Which I never thought I was gonna do but I did take my family away from him and travel home, but he followed me, he tried to sweet talk to me and everything...I end up back with him, stayed out there for him, with him...I went through hard times with him and everything, my kids knew about it [the violence].

Annie's description of "managing" to be with him is clear. For Annie, it appeared that remaining with the man who had become her life partner was expected; she never thought that she would leave him. Leaving was extremely difficult and took great perseverance; perhaps it was dangerous, perhaps it was not what a woman was supposed to do. It is possible that Annie's determination in "managing" to be with him was based on her understanding of a woman's role; whether that understanding came from a cultural prescript or some other source cannot be known. For example, perhaps Annie remained with John because his treatment of her was similar to what she saw growing up. Perhaps it is all of those reasons (or none of them), but, whatever the explanation, Annie remained with John despite the violence and abuse. She used the word "managed" in her phrase "I managed to get away with my family," and she goes on to say that this was something she never thought she would do. Leaving him was not an option; going back home to her reservation would require money and transportation that she did not have. Ultimately it was not what Annie believed was the right thing to do unless it became too dangerous to stay. Annie's place was beside John; that was the place where a strong woman would remain.

It was as though Annie had drawn a line in the sand; she had developed the ability to live within a specified level of abuse and violence, and then one night John's violence got "out of hand" as he stepped over the line of what had become normalized violence. Annie believed that she had to defend her life against his violence. When asked what steps she had taken in the past to protect herself from John, Annie responded that she called the police numerous times and had obtained orders of protection on two separate occasions, only to have police tell her partner to take a walk and cool off. One of the times that Annie and the children left John, they fled to Annie's sister's home on the reservation. Unfortunately, John found her, and in an attempt to get her to return 
with him to their home in the city, he took an axe to her sister's house and threatened to burn it down. John's message was clear; her place was with him.

\section{They're in my footstep all the way now}

The second theme uses Annie's words to deconstruct her relationship with her children. This theme embodies Annie's struggle to protect and preserve her family and allows us to examine one of Annie's crucial mechanisms for survival-her relationship with her children. Annie described how she managed to motivate herself to survive:

...I tried to defend myself, me and my kids...tried to keep my family with me, every day, every month...try to be a tough woman, try to stand in there for my kids, it's hard but I'm gonna be strong forever for my kids.

It is clear that Annie was driven to safeguard her children as best she could. It also appears that she drew strength from her role as a mother, strength that may have eventually propelled her towards ending her violent relationship. However, it may also be possible that Annie stayed in her abusive relationship for as long as she did because she did not want to break up her family. Thus, we see that this theme can be interpreted as Annie protecting her children and ending her violent relationship, or as Annie protecting her family and staying in her violent relationship.

This theme also exposes the realization that Annie's children were aware of the violence between their mother and father as it occurred, and that her children may be perpetuating the cycle of violence in their own relationships today. Annie expressed these ideas regretfully:

...I never did want my kids to go through the same thing that I went through with John... They knew a lot about what John used to do to me and how I used to defend myself... I think my kids are to that point where you know they can't control themselves... They just go by the way their mom or their dad, whoever... went through all that life; that's how they pick it up... My kids are going through the same old thing, verbal abuse, jealousy, same old thing I went through... They're in my footstep all the way now, which I never did wanted them to do. 
Annie articulated that she was abused, her children witnessed it, and now her children are in violent relationships. It seems as though Annie understands the cyclical patterns that often emerge in families where violence occurs. However, she does not appear to understand how to break the familial cycle of violence:

... They can't control it no more. I think that's what my kids are going through right now, but I'm trying to be there for them...try to talk to them and everything and they just go by the way their mom or dad [did]...that's how they pick it up.

Annie's frustration with her children's situation is palpable. She seems to feel as though there is little she can do to help the situation. John abused Annie; the children witnessed it; and now they carried the violence into their own adult relationships. On one hand, it sounds like Annie understands that by being available to her children she can be supportive of them in their struggle, yet, at the same time, her helplessness seems clearly visible. I wondered if what I perceived as helplessness might feel uncomfortably similar to how she felt with John.

\section{What's a Miranda right?}

Instead of naming the legal right for witnesses to refrain from incriminating themselves, the police detective on the night of her arrest advised Annie of her Miranda rights, and that moment became a metaphor for the difficulties she experienced with English. Though she didn't question this at the time of her arrest, when she talked about it later she asked, "What's a Miranda right?" Annie did not understand the full meaning of the Miranda Warning (Miranda v. Arizona, 1966) or perhaps did not know how to access help; nor was help offered in terms of language.

...I remember that they did the Miranda rights to me that time when they picked me up. I didn't understand...they read me a Miranda right and I said what's a Miranda right? And he [detective] said that's where they tell you that [you] got picked up for something that you did...that's the only thing I remember. 
For example, her public defender requested that the court appoint an interpreter for the trial. It was not until I interviewed Annie for this article, several years after her release from prison, that she spoke about what transpired during trial.

I kind of didn't understand [the court-appointed interpreter] because me and her, her language was different....and there was three different ways I could use when I try to speak to her... but [in] her way there was [only] one way so it was kind of hard for me... Even though we speak the same language, but she didn't understand. I used to tell her what are you saying? I used to tell her that, you know, in the [tribal] way there's lots of ways I could say something but she only said it to me in one way. That's how it was; it was kind of hard for me to understand my interpreter.

This is yet another example of how pervasive language differences and misunderstandings are throughout Annie's story. Annie told the story in what I had become accustomed to as her usual voice, i.e., quiet, reserved, matter-of-fact. When asked if she had told anyone about the difficulty understanding the interpreter during trial, Annie responded that she had not. Had she simply learned not to ask for help, or had she become accustomed to things not working to her benefit? Had experience taught her that this is just the way it is?

Language difficulties kept finding their way into Annie's story about John. She described being homeless with a toddler in the city a few months before meeting John. She stated that she asked John if she and her son could move into John's grandfather's home for a short time while she found a place to live. She went on to say that John had misunderstood what she was asking and assumed that she wanted to live with him in an intimate way. She stated that she did not know that that was what he thought until she tried to rebuff his sexual advances, something which he would not tolerate. It wasn't until years later in a drunken rage when John used the word "rape" that Annie was able to apply that word to what had been happening to her all the years that they had been together. She stated that the word rape does not exist in her native language. Ironically, she hadn't known the meaning of the word until her abuser named the violence. 


\section{Summary of Themes}

It is clear that each theme becomes a small piece of the story of Annie's complex personhood (Gordon, 1997). In the first theme, we see Annie as a survivor of domestic violence. We hear about her two failed attempts to escape; her fear of John and how John got "out of hand." In the second theme we see her concern for her children and the effects that witnessing violence has on their lives today. In the final theme we are witness to the impact that language has on Annie's life. These themes can be viewed as aspects of Annie's multiple identities including Al woman, mother, victim of IPV, and offender. Taken individually, each theme is powerful, but combined they reveal a story of a woman who wants to be "tough" and wants to "stand in there forever" for her children. The methodology allows us to uncover all of these identities and to reveal the complex personhood that defines Annie.

\section{Limitations}

As a case study of one woman's experiences, generalizability of the themes is not a goal, nor is it a possibility. Kasturirangan, Krishnan, and Riger (2004) aptly point to the barriers that may exist between a researcher and her participants when their backgrounds are dissimilar. As is likely in many research projects, a power imbalance can exist between the participant and researcher. In the specific case of this research the power differential between the researcher and the participant's membership in multiple vulnerable groups is clear. The implications of this power differential can be substantial from the participant's initial agreement to participate in the research through the dissemination of her words. Kasturirangan, Krishnan, and Riger (2004) also discuss researchers' assumed homogeneity of groups of people lumped together as one cultural group. It is important to note that even within Al/AN nations, women's experiences may vary greatly. Complicating the issue of assumed homogeneity are the multiple identities of many research participants, in general, and specifically, those multiple identities that contribute to Annie's experiences.

Nevertheless, the choice of using a case study as the unit of analysis is a reflection of the research team's hope that by illuminating one Al woman's experiences, it would bring to light some of the meanings Annie constructed based on her experiences. Annie's belief that there was no way to escape John's violence and abuse could be an extension of her lived experience of poverty, knowledge of an unresponsive criminal justice system, and internalized oppression. 


\section{Discussion}

Researchers are just beginning the process of exploring the complex link between victimization and offending as it applies to battered women. Quantitative research, while invaluable, would not have allowed us to understand the intricacies and intimacies of Annie's story. She would have become a number or percentage, and her life would have been distilled into statistics. It can be argued that all battered women who take the life of their batterer are likely to have a complex story in which multiple identities, inadequate criminal justice response, and/or poverty may play a role. I would argue that Annie's experiences of victimization and offending are further complicated by her multiple identities that turn themselves against her to become intersecting oppressions (Hill Collins, 2000, p. 25). Furthermore, to extract Annie's experiences from her cultural identity is impossible. Interestingly, research that focuses on the lives of women who have experienced IPV is replete with statements about the need to retain the context in which the violence occurred so as not to distill the violence into discrete acts without acknowledging the abuse as the background of the story (Dasgupta, 2002; Dobash \& Dobash, 1979; Dobash, Dobash, Wilson, \& Daly, 1992; Kimmel, 2002; Walker, 1984). So, too, is it critically important to maintain the multiple identities of women like Annie for whom cultural identity forms the core of their existence, defines their life, and creates a world in which few options are available. Annie was isolated from her language, traditions, family, friends, and community during the 20 years in which she lived with John. Upon release from prison Annie immediately returned to her community; she went home.

Annie's story cannot be separated from the historical context that she carries as an Al woman and the context of IPV in which she lived. She has been identified and defined as a felon by the state's criminal justice system and now by her Al community. As such, she has lost the federal housing she once had in her community and has had great difficulty finding employment. "Felon" and "offender" have become the words that now define who she is, what she can do, and where she can live. The phrase "victim and offender" offers yet another inadequate explanation of the intersecting oppressions that have defined Annie's life (Hill Collins, 2000, p. 25). Words such as "woman of color,"'"felon,"'offender," and "victim of intimate partner violence," taken individually, expunge the social conditions of Annie's life and fail to acknowledge the multiple levels of complex personhood that are Annie. 
Sharon Murphy, Ph.D., ACSW

University of New Hampshire

Social Work Department

Pettee Hall

55 College Road

Durham, NH 03824

E-mail: sharon.murphy@unh.edu

Phone: 603/862-3826

\section{References}

Agtuca, J. (2008). Beloved women: Life givers, caretakers, teachers of future generations. In S. Deer, B. Clairmont, C. Martell, \& M. White Eagle (Eds.), Sharing our stories of survival (Chapter 1). Lanham, MD: Altamira Press.

Allen, P. G. (1992). The sacred hoop. Boston: Beacon Press.

Bohn, D. (2003). Lifetime physical and sexual abuse, substance abuse, depression, and suicide attempts among Native American women. Issues in Mental Health Nursing, 24, 333-352.

Bradley, R.G., \& Davino, K.M. (2002). Women's perceptions of the prison environment: When prison is "the safest place I've ever been." Psychology of Women Quarterly, 26, 351-359.

Browne, A., Miller, B., \& Maguin, E. (1999). Prevalence and severity of lifetime physical and sexual victimization among incarcerated women. International Journal of Law and Psychiatry, 22, 301-322.

Bubar, R., \& Thurman, P.J. (2004). Violence against native women. Social Justice, 31, 70-84.

Bureau of Indian Affairs. (2008). Retrieved January 4, 2008 from http:// www.doi.gov/bureau-indian-affairs.html

Bureau of Justice Statistics. (2004) American Indians and Crime: A BJS Statistical Profile, 1992-2002. Retrieved January 4, 2008 from http:// www.ojp.usdoj.gov/bjs/abstract/aic02.htm 
Bureau of Justice Statistics. (2006). Intimate partner violence (IPV) in the U.S. Retrieved on June 13, 2007 from www.ojp.usdoj.gov/bjs/ intimate/ipv.htm

Chesney-Lind, M., \& Pasko, L. (2004). The female offender (2nd ed.). Thousand Oaks, CA: Sage Publications.

Chester, B., Robin, R.N., Koss, M.P., Lopez, J., \& Goldman, D. (1994). Grandmother dishonored:Violence against women by male partners in American Aboriginal communities. Violence and Victims, 9, 249258.

Clark, R.L., \& Johnson, C.L. (2008). Overview of issues facing Native women who are survivors of violence in urban communities. In S. Deer, B. Clairmont, C. Martell, \& M. White Eagle (Eds.), Sharing our stories of survival (pp. 87-99). Lanham, MD: Altamira Press.

Dasgupta, S.D. (2002). A framework for understanding women's use of nonlethal violence in intimate heterosexual relationships. Violence Against Women, 8, 1364-1389.

Deer, S., Clairmont, B., Martell, C., \&White Eagle, M. (Eds.). (2008). Sharing our stories of survival. Lanham, MD: Altamira Press.

Deloria, V. Jr., \& Lytle, C. (1983). American Indians, American justice. Austin, TX: University of Texas Press.

Desai, S., \& Saltzman, L. (2001). Measurement issues for violence against women. In C. Renzetti, J. Edleson, \& R.K. Bergen (Eds.), Sourcebook on violence against women. Thousand Oaks, CA: Sage Publications.

DeVault, M. (1990). Talking and listening from women's standpoint: Feminist strategies for interviewing and analysis. Social Problems, 37(1), 96-116.

Diekelmann, N., \& Allen, D. (1989). A Hermeneutic analysis of the National League for Nursing criteria for the appraisal of baccalaureate programs. In N. Diekelmann, D. Allen, \& C. Tanner (Eds.), The NLN Criteria for Appraisal of Baccalaureate Programs: A Critical Hermeneutic Analysis, (pp. 11-31). New York: National League for Nursing.

Dobash, R., \& Dobash, R. P. (1979). Violence against wives: A case against the patriarchy. NY: Free Press.

Dobash, R. P., Dobash, R. E., Wilson, M., \& Daly, M. (1992). The myth of sexual symmetry in marital violence. Social Problems, 39, 71-91. 
Duran, E., \& Duran, B. (1995). Native American postcolonial psychology. Albany, NY: State University of New York Press.

Ferraro, K. (2006). Neither angels nor demons. Boston: Northeastern University Press.

Gordon, A. (1997). Ghostly matters. Minneapolis: University of Minnesota Press.

Grafanaki, S. (1996). How research can change the researcher: The need for sensitivity, flexibility and ethical boundaries in conducting qualitative research in counseling/psychotherapy. British Journal of Guidance \& Counseling, 24, 329-339.

Hamby, S. L. (2000). The importance of community in a feminist analysis of domestic violence among American Indians. American Journal of Community Psychology, 28(5), 649-669.

Harwell, T.S., Moore, K.R., \& Spence, M.R. (2003). Physical violence, intimate partner violence, and emotional abuse among adult American Indian men and women in Montana. Preventive Medicine, 37, 297-303.

Heidegger, M. (1996). Being and time. (J. Stambaugh, Trans.). Albany, NY: State University of New York Press. (Original work published 1953).

Hill Collins, P. (2000). Black feminist thought. New York: Routledge.

Jaimes, M.A. (1992). The state of Native America. Boston: South End Press.

Kasturirangan, A., Krishnan, S. \& Riger, S. (2004). The impact of culture and minority status on women's experience of domestic violence. Trauma, Violence, \& Abuse, 5, 318-332.

Kimmel, Michael S. (2002). Gender symmetry in domestic violence: A substantive and methodological research review. Violence Against Women, 8, 1332-1363.

Lobe, J. (2007). One in three Native women suffer sexual assault. Inter Press Service News Agency [IPS]. Retrieved June 25, 2007 from http://www.ipsnews.net/news.asp?idnews=37493

Lujan, C. (1995). Women warriors: American Indian women, crime and alcohol. Women and Criminal Justice, 7, 9-33.

Miller, S. (2001). The paradox of women arrested for domestic violence. Violence Against Women, 7(12), 1339-1376. 
Miranda v. Arizona, 384 U.S. 436 (1966).

Murphy, S., Gerdes, K., Risley-Curtiss, C. (2004). American Indian women and domestic

violence: The lived experience. Human Behavior in the Social Environment, 7(3/4), 159-181.

Murray, V. H. (1998). A comparative survey of the historic, civil, common, and American Indian tribal law responses to domestic violence. Oklahoma City University Law Review, 23, 433-457.

Oetzel, J., \& Duran, B. (2004). Intimate partner violence in American Indian and/or Alaska Native communities: A social ecological framework of determinants and interventions. American Indian and Alaska Native Mental Health Research, 11(3), 49-68.

Owen, B. (2001). Perspectives on women in prison. In C.M. Renzetti, \& L. Goodstein (Eds.), Women, crime, and criminal justice: Original feminist readings, Los Angeles, CA: Roxbury Publishing Company.

Rivers, M.J. (2005). Navajo women and abuse: The context for their troubled relationships. Journal of Family Violence, 20, 83-89.

Saylors, K. \& Daliparthy, N. (2006). Violence against native women in substance abuse treatment. American Indian and Alaska Native Mental Health Research, 13(1) 32-51.

Steffensmeier, D., \& Allan, E. (1996). Gender and crime:Toward a gendered theory of female offending. Annual Review of Sociology, 22, 459487.

Straus, M. A. (1979). Measuring intrafamily conflict and violence: The conflict tactics (CT) scales. Journal of Marriage and the Family, 41(1), 75-88.

Straus, M. A. (1993). Physical assaults by wives: A major social problem. In R.J. Gelles \& D.R. Loseke (Eds.), Current controversies on family violence (pp. 67-80). Newbury Park, CA: SAGE.

Straus, M.A., Gelles, R. \& Steinmetz, S. (1980). Behind closed doors:Violence in the American family. Garden City, NY: Anchor/Doubleday.

Tjaden, P.\&Thoennes, N. (1998). Prevalence, incidence, and consequences of violence against women: Findings from the National Violence against Women Survey. Research in brief. Retrieved March 12, 2008 from http://www.ncjrs.gov/pdffiles/172837.pdf 
U.S. Census Bureau. (2000). Statistical abstract of the United States. Washington, DC: U.S. Government Printing Office.

Wahab, S., \& Olson, L. (2004). Intimate partner violence and sexual assault in Native American communities. Trauma, Violence \& Abuse, 5(4), 353-366.

Walker, L., (1984). The battered woman syndrome. NY: Springer.

Waller, M., Risley-Curtiss, C., Murphy, S., Medill, A. \& Moore, G. (1998). Harnessing the power of language: American Indian women, a case example. Journal of Poverty, 2(4), 63-81.

Zion, J.W., \& Zion, E.B. (1993). 'Hozho's Sokee'—stay together nicely: Domestic violence under Navajo common law. Arizona State Law Journal, 25, 407-426.

\section{Footnotes}

${ }^{1}$ Annie and John are pseudonyms.

2 The first author provided domestic violence expert testimony at Annie's trial and clemency review process.

${ }^{3}$ This case study is not a part of a larger study, nor is it funded research. 